OPEN ACCESS

Edited by:

Peng Bao,

Institute of Urban Environment (CAS),

China

Reviewed by:

Guorong Zhu,

Henan Normal University, China

Yibo Wu,

Ningbo University, China

*Correspondence:

Xiaolin Zhang

zhangx|@ihb.ac.cn

${ }^{t}$ These authors have contributed equally to this work and share first

authorship

Specialty section:

This article was submitted to

Freshwater Science,

a section of the journal

Frontiers in Environmental Science

Received: 08 May 2021 Accepted: 18 June 2021

Published: 09 July 2021

Citation:

Yuan C, Bai X, Zhu T, Wen Z, Cao T, Zhang $X$ and Ni L (2021) Long-Term Effects of the Harvesting of Trapa natans on Local Water Quality and Aquatic Macrophyte Community in

Lake Erhai, China.

Front. Environ. Sci. 9:706746. doi: 10.3389/fenvs.2021.706746

\section{Long-Term Effects of the Harvesting of Trapa natans on Local Water Quality and Aquatic Macrophyte Community in Lake Erhai, China}

\author{
Changbo Yuan ${ }^{1 \dagger}$, Xiaohu Bai ${ }^{2,3,4,5+}$, Tianshun $\mathrm{Zhu}^{6}$, Zihao Wen ${ }^{1}, \mathrm{Te} \mathrm{Cao}^{1}$, Xiaolin Zhang ${ }^{1 *}$ \\ and Leyi $\mathrm{Ni}^{1}$ \\ ${ }^{1}$ Donghu Experimental Station of Lake Ecosystems, State Key Laboratory of Freshwater Ecology and Biotechnology, Institute of \\ Hydrobiology, Chinese Academy of Sciences, Wuhan, China, ${ }^{2}$ Xinjiang Academy of Environmental Protection Science, Urumqi, \\ China, ${ }^{3}$ Xinjiang Key Laboratory for Environmental Pollution Monitoring and Risk Warning, Urumqi, China, ${ }^{4}$ Xinjiang Engineering \\ Technology Research Center for Cleaner Production, Urumqi, China, ${ }^{5} \mathrm{Jung}$ gar Desert-oasis Ecotone Station for Scientific \\ Observation and Research of National Environmental Protection, Urumqi, China, ${ }^{6}$ College of Life Sciences, Zaozhuang University, \\ Zaozhuang, China
}

Trapa natans is one of the main species causing the swamping in the littoral zones of Erhai Lake. It commonly forms a dense canopy on the water surface in the growing season (June-September), which hampers the local water quality and habitat of submerged macrophytes, and releases nutrients to the water after death in autumn and winter, resulting in the deterioration of local water quality. At present, there are many and positive research studies on the short-term effects of harvesting water chestnut on water quality and aquatic plants, but long-term observation results are lacking. In response to the above problems, we studied responses of water quality and aquatic plant community to the removal of Trapa in littoral zone of a northern bay in Erhai from August 2014 to January 2017. This could be the first attempt to discover the long-term effects of floating-leaved vegetation management in the freshwater ecosystem. The results showed that the artificial removal of Trapa significantly improved the local water quality in the growing season, for example, the concentrations of total nitrogen (TN), dissolved nitrogen (DN), total phosphorus (TP), and dissolved phosphorus (DP) in the non-Trapa zone (NTZ) were much lower than the concentrations of those in the adjacent Trapa zone (TZ). And the biomass of aquatic macrophyte community (BAMC) was significantly increased in the NTZ, up to the maximum value of about $21 \mathrm{~kg} / \mathrm{m}^{2}$ in fresh weight. However, the diversity indexes of the community in the NTZ declined. Therefore, we suggested that although the removal of Trapa improved the water quality and increased the productivity of the submerged aquatic plant community, it reduced the species diversity of the aquatic plant community in the long run. This is another issue that we need to pay attention to in the later management in Erhai Lake.

Keywords: harvesting, water quality, aquatic plant community, Lake Erhai, Trapa natans 


\section{INTRODUCTION}

Trapa species are typical floating-leaved aquatic plants. The floating-leaved plants are obviously superior for light competition than submersed plants, and the only limited factor which could prevent their growth is nutrients. As aggravation of the water eutrophication, floating-leaved species would quickly outcompete other aquatic plants and become dominant species in many shallow water bodies (Kočić et al., 2009; Chen and Wang, 2019). As the water temperature and the input of external nutrients increase, their biomass will further increase, leading to the deepening of the eutrophication of the ecosystem and threatening the ecological balance of the habitat (Markovic et al., 2015).

On the one hand, Trapa has serious negative effects on water bodies during the growing season and the decline season. In the growing season, Trapa can reach a high biomass, for example, $504 \pm 91$ g dry Weight $/ \mathrm{m}^{2}$ in Lake Lanca di Po (Bolpagni et al., 2007), thereby adsorbing a large amount of nutrients, most of which is from the sediment (Watanabe et al., 2010). At the same time, it forms an underwater environment of high total phosphorus concentration (Akabori et al., 2015). In addition, most of the nutrients absorbed by Trapa are released to the water column after their death and decomposition in autumn and winter, hampering the local water quality (Choi et al., 2016).

On the other hand, the existence of Trapa species inhibits the propagation and spread of submerged plants, and threatens the living environment of other organisms (Caraco and Cole, 2002) by forming water environment of low oxygen concentration (Hummel and Findlay, 2006; Goodwin et al., 2008; Kato et al., 2016; Klančnik et al., 2017), low light intensity (30\% coverage can block $74 \%$ of the light) (Netten, 2011), and so on, which in turn affects the service functions of lake ecosystems (Markovic et al., 2015). The low oxygen content and low underwater light intensity in local waters caused by Trapa species (Caraco and Cole, 2002; Kara et al., 2010; Klančnik et al., 2017) severely inhibit photosynthesis intensity of submerged macrophytes (Barko and Smart, 1981). Once the abundance of the floating-leaf plants develops rapidly through its asymmetric competitive advantage over submerged macrophytes and exceeds a certain threshold, submerged macrophytes will face the threat of decay, which will seriously weaken the health and stability of the lake ecosystem (Scheffer et al., 2003; Kagami et al., 2019).

At present, there are a few research studies on the harvesting management of Trapa, and they mainly focus on the short-term (within 1 year) effects of reducing the nutrient load of water bodies (Galanti et al., 1990; Xu et al., 2014; Lawniczak and Achtenberg, 2018), lacking results of long-term monitoring of harvesting Trapa on water quality and the plants. These shortterm results showed that the harvesting of Trapa significantly reduced the concentrations of nitrogen and phosphorus in the water body, and promotes the growth of some subdominant aquatic plants. The removal of Trapa will definitely improve the submerged plant community to a certain extent (Xu et al., 2014), but the recovery of aquatic plant community after Trapa harvesting is a long run, which has also an important effect on local water quality. Thus, these results are difficult to apply to actual aquatic plant management because the stabilization of aquatic plant community composition requires a long-term process. As Scheffer et al. (2003) indicated by the model approach, the competition relationship between floating and submersed plants can cause alternative attractors. However, such a hypothesis still needs a useful complementary type of evidence through large-scale field experiments (Scheffer et al., 2003).

Therefore, in order to explore the long-term response of water quality and aquatic vegetation to harvesting of the Trapa population, we conducted a 30 -month study in the northern bay of Erhai Lake. Our research could be the first attempt to experimentally evaluate the ecological functions of floatingleaved plant management through long-term and large-scale field experiment. And our results will provide a valuable and practicable management strategy in the large-scale ecological restoration.

Based on the limited research studies (Scheffer et al., 2003; Xu et al., 2014), it is reasonable to expect that submersed macrophyte community will gradually recover after the removal of Trapa populations. But the further community succession and ecosystem management still need to be studied. In this research, we hypothesized that 1) the removal of the Trapa population will significantly improve the local water quality, 2) the submersed macrophytes will reassemble soon after the removal of Trapa, and 3) the local biodiversity will be improved dramatically.

\section{MATERIALS AND METHODS}

\section{Study Area}

This research was conducted in Haichao Bay, which is in the northern part of Erhai Lake $\left(25^{\circ} 52^{\prime} \mathrm{N}, 100^{\circ} 06^{\prime} \mathrm{E}\right)$ in subtropical Yunnan Plateau, China. It was adjacent to the breeding base of Erhai aquatic plant seedlings without seasonal pollutant inputs. Erhai Lake is a mesotrophic lake with a moderate water depth (max. $20.5 \mathrm{~m}$, mean. $10.5 \mathrm{~m}$ ) and has an area of about $250 \mathrm{~km}^{2}$. In the last decades, with the increased eutrophication of the local watershed, the littoral zone of Haichao Bay was dominated by $T$. natans, and the submerged vegetation was seriously threatened (Fu et al., 2013).

\section{Experiment Design}

The experiment was conducted in shallow waters near Baima village on the west bank of Haichao Bay. It was divided into two experimental zones (Figure 1). One was enclosed by a polyethylene mesh to an area of about $20,000 \mathrm{~m}^{2}$. In this zone, T. natans was repeatedly removed with a sickle from August 16, 2014 to August 25, 2014 as the non-Trapa zone (NTZ) treatment. The second (control zone) without harvesting was adjacent to the NTZ with the area of about $10,000 \mathrm{~m}^{2}$ and was treated as the Trapa zone (TZ) treatment (Figure 1). Monitoring sites were deployed as below and were sampled monthly (except December 2016 for the lacking of personnel and sampling tools) from August 15, 2014 to January 15, 2017, for measurements of water quality parameters and aquatic plant community 


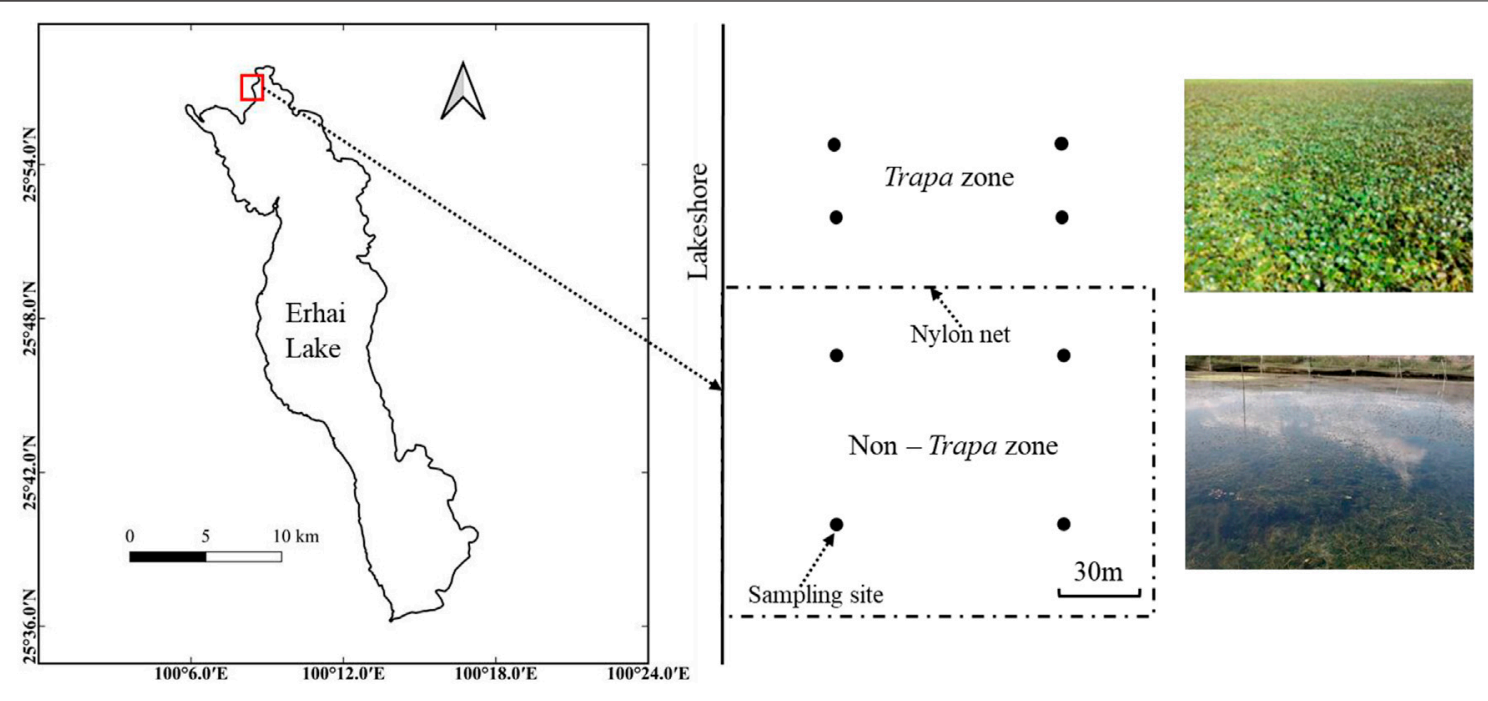

FIGURE 1 | Sketch map of study area location.

indexes. The growing season of aquatic plants was from June to September each year. There was cross-regional water exchange between these two zones, so we set the distance between the sampling sites to be greater than $30 \mathrm{~m}$ to reduce this impact.

\section{Data Collection}

The water column physical indicators, including water temperature $(\mathrm{T}), \mathrm{pH}$, and dissolved oxygen (DO), were measured on each site using a multiparameter analyzer of water quality (Yellow Springs Instruments, Ohio, United States) at the depth of $1 \mathrm{~m}$. A mixed 2.5-L water sample was collected by an improved 5-L Patalas water collector from the upper, middle, and lower parts of the water column at each site for each sampling. The water sample was stored in an incubator with ice cubes and transferred to lab for analysis of total nitrogen (TN), total phosphorus (TP), nitrate nitrogen $\left(\mathrm{NO}_{3}-\mathrm{N}\right)$, ammonium nitrogen $\left(\mathrm{NH}_{4}-\mathrm{N}\right)$, dissolved nitrogen (DN), dissolved phosphorus (DP), soluble reactive phosphorus (SRP), and chlorophyll a (Chl-a) according to methods described by Eaton et al. (1995).

At each site, the aquatic macrophyte community was sampled thrice randomly using a scythe-type sampler (sampling area $0.2 \mathrm{~m}^{2}$ ). Each species was identified, and its fresh weight was estimated immediately for the measurement of biomass of macrophyte community (BMC). The Shannon-Weiner index (SWI), Pielou's evenness index (PE), and Simpson's diversity index $(\mathrm{SDI})$ were calculated as SWI $=-\sum\left(P_{i}\right)\left(\ln P_{i}\right)\left(P_{i}\right.$ for biomass percentage of each species), $\mathrm{PE}=H / H_{\max }$ ( $H$ for actual species diversity index; $H_{\max }=\operatorname{Ln}(S), S$ is the number of all species), and SDI $=1-\sum P_{i}^{2}\left(P_{i}\right.$ has the same meaning as above).

\section{Statistical Analysis}

The results were expressed in the form of mean \pm standard error. To test the effects of Trapa removal on local water quality in different seasons, the pairwise t-test was used to analyze the differences of all water physical and chemical parameters between the two zones. To examine the response of aquatic plant community after Trapa removal in different seasons, the oneway ANOVA was used to test the differences of aquatic plant biomass and community diversity between the two zones. The differences in the indexes of water quality and aquatic plant community between the TZ and NTZ adopted the method of analysis of covariance (ANCOVA), taking the sampling time as the covariate. All data were tested for normality and homogeneity before analysis, and $\log (\mathrm{x}+1)$ or $\log (1 / \mathrm{x})$ conversion was performed on data that do not meet the above conditions. If the test standard was not met, the corrected result will be the output after the correction. The significance levels were all set to $p<0.05$. The statistical analysis was completed by SPSS 22.0 software (SPSS, Chicago, IL).

\section{RESULTS}

\section{Water Qualities Between Two Zones}

There was no significant difference in water temperature between the two zones in most months $(p>0.05)$, and the overall characteristic of seasonal fluctuations is high in summer and autumn and low in winter and spring, with a range of about $11-29^{\circ} \mathrm{C}$ (Figure 2A). In terms of dissolved oxygen content in the water column, the two zones had significant differences $(p<$ 0.05 ), and the TZ had significantly lower oxygen content than the NTZ $(p<0.05)$ (Figure 2B). During the summer and autumn seasons, the dissolved oxygen content in the $\mathrm{TZ}$ remained at a low level, with an average value below $4.5 \mathrm{mg} / \mathrm{L}$, while the dissolved oxygen in the NTZ during the same period was above $6 \mathrm{mg} / \mathrm{L}$, and the highest value was close to $12 \mathrm{mg} / \mathrm{L}$ (Figure 2B). There was no significant difference in water $\mathrm{pH}$ in the two zones $(p>0.05)$, and both show the characteristics of high in summer and low in winter (except for a sudden drop in June-August 2015), and the overall range of changes was between 6.9 and 10.5 (Figure 2C). The average water depth of the two zones during the experiment 

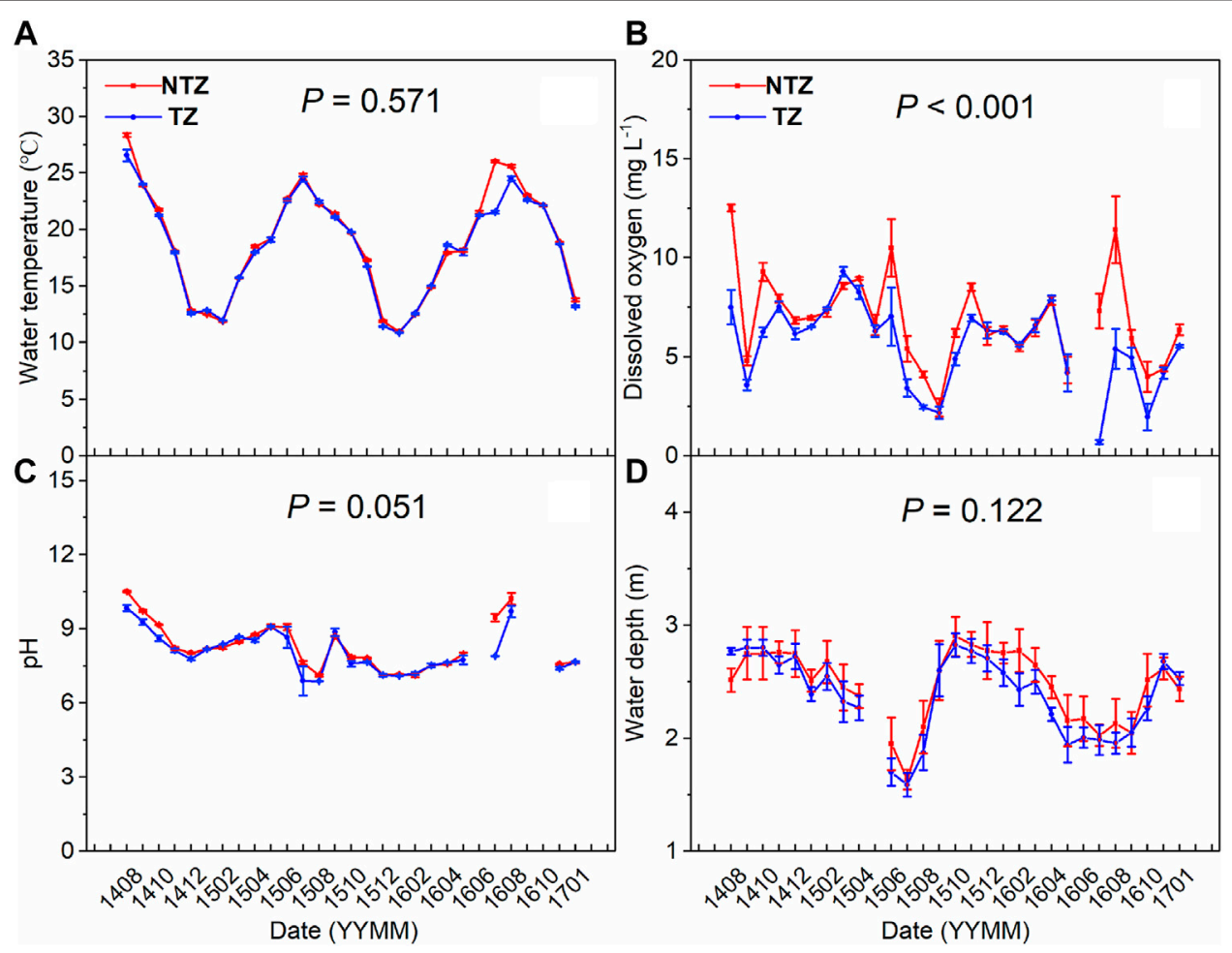

FIGURE 2 |Water physical parameters of two experimental zones (NTZ, non-Trapa zone; TZ, Trapa zone; number of replicates: 4). (A) water temperature; (B) pH of water column; (C) dissolved oxygen in water column; (D) water depth.

period was between about 1.5 and $3 \mathrm{~m}$, and there was no significant difference between them $(p>0.05)$ (Figure 2D).

Water chemical indexes were maintained relatively stable for the NTZ, except $\mathrm{NH}_{4}-\mathrm{N}$ and $C h l-a$, in the whole experiment time. Mean values of TN, TP, $\mathrm{PO}_{4}-\mathrm{P}$, and Chl$a$ in the NTZ were $0.82 \pm 0.05 \mathrm{mg} / \mathrm{L}, 0.039 \pm 0.04 \mathrm{mg} / \mathrm{L}$, $0.023 \pm 0.003 \mathrm{mg} / \mathrm{L}$, and $16.20 \pm 2.27 \mu \mathrm{g} / \mathrm{L}$, respectively (Figure 3).

According to all forms of nitrogen, there was a significant difference between the TZ and NTZ during the period from May to August in each year $(p<0.05)$ (Figures 3A-D). Specifically, TN in the NTZ showed a significant upward trend in the second month $(p<0.05)$ after harvesting and was then maintained relatively stable (Figure 3A). The variation range of TN in the NTZ was $0.5-1.25 \mathrm{mg} / \mathrm{L}$, with the highest values during June and August of each year. In July 2015, the TN concentration in the two zones reached the highest values, which were $2.20 \pm 0.38 \mathrm{mg} /$ $\mathrm{L}$ and $1.26 \pm 0.29 \mathrm{mg} / \mathrm{L}$, respectively, and the TN concentration of the TZ was about $74.6 \%$ higher than that of the NTZ (Figure 3A). Before July 2016, the TN in the NTZ remained relatively stable, while it increased significantly in the $\mathrm{TZ}$ in January and February 2016 and was significantly higher than that of the NTZ $(p<0.05)$ (Figure 3A). After July 2016, there was no significant difference in the TN between the two zones $(p<0.05)$ (Figures 3A-D). The changing trends of $\mathrm{DN}$ and $\mathrm{NO}_{3}-\mathrm{N}$ in the two zones were similar to those of TN (Figures 3B,D). The concentration of $\mathrm{NH}_{4}-\mathrm{N}$ in the two zones remained stable below $0.2 \mathrm{mg} / \mathrm{L}$ throughout the experimental period, except in August 2015 and June 2016 (Figure 3C).

The three forms of phosphorus (TP, DP, and SRP) varied similarly during the experiment period (Figures 3E-G). All of them were significantly higher in the TZ than those in the NTZ (Figures 3E-G). The TP concentration of the NTZ remained below $0.1 \mathrm{mg} / \mathrm{L}$ during the entire experimental period (Figure 3E), while it was much higher in the TZ, especially in summer. For instance, in June 2016, it was about $0.189 \pm$ $0.030 \mathrm{mg} / \mathrm{L}$ in the TZ, almost 4.5 times than that in the NTZ $(p<0.05)$ (Figure 3E).

Chl-a represents the abundance of phytoplankton in a water column. Two months after harvesting (October 2014), the concentration of Chl-a in the NTZ increased dramatically and reached $41.68 \pm 3.28 \mu \mathrm{g} / \mathrm{L}$, while at the same time, in the $\mathrm{TZ}$, it was $11.51 \pm 3.19 \mu \mathrm{g} / \mathrm{L}$ (Figure $3 \mathbf{H}$ ). After that, there was no significant difference in the concentration of Chl-a between the two zones $(p>0.05)$ (Figure 3H).

\section{Aquatic Plant Community Between Two Zones}

During the entire experimental period, the aquatic plant communities in the two zones contained 11 species (Table 1). From August 2014 to August 2015, aquatic plants experienced the first recovery period after harvesting. The biomass of the aquatic plant community in the NTZ increased from $9.18 \pm 0.51$ to 

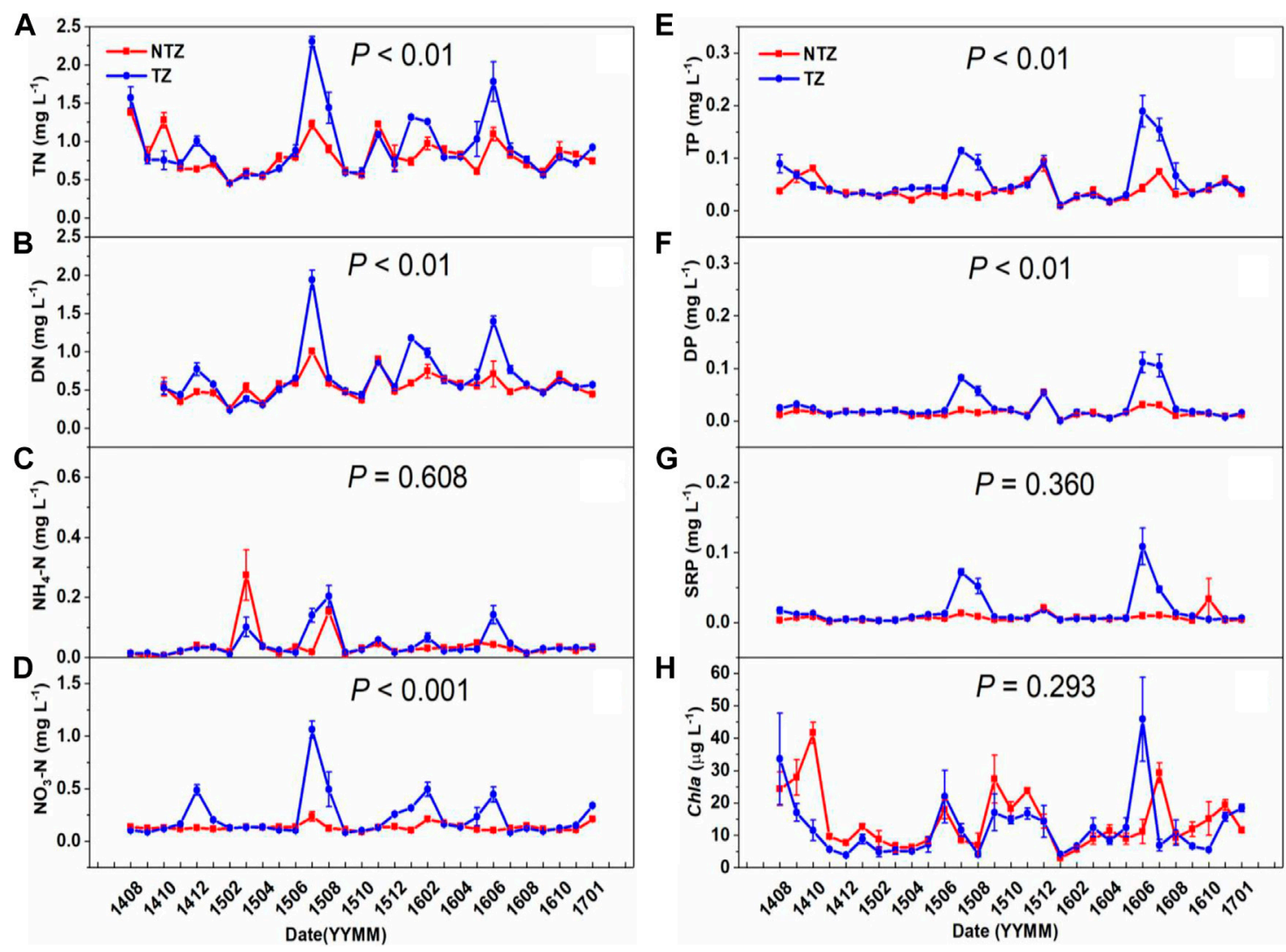

FIGURE 3|Water chemical parameters of two zones (NTZ, non-Trapa zone; TZ, Trapa zone; number of replicates: 4). (A) total nitrogen; (B) dissolved nitrogen; (C) ammonium nitrogen; (D) nitrate nitrogen; (E) total phosphorus; (F) dissolved phosphorus; (G) soluble reactive phosphorus; (H) chlorophyll a.

TABLE 1 | List of aquatic plant species in two zones before harvesting.

\section{Family}

Trapaceae

Ceratophyllaceae

Haloragaceae

Hydrocharitaceae

Potamogetonaceae

-

$-$

$-$

$-$

$-$
Genus

\section{Trapa}

Ceratophyllum

Myriophyllum

Vallisneria

Hydrilla

Potamogeton

$-$

-

$-$

$-$

Stuckenia
Species

Trapa natans Ceratophyllum demersum Myriophyllum spicatum Vallisneria natans Potamogeton acutifolius Potamogeton maackianus Potamogeton intortifolius Potamogeton lucens Potamogeton crispus Stuckenia pectinata Hydrilla verticillata

$17.27 \pm 2.80 \mathrm{~kg} / \mathrm{m}^{2}$. At the same time, the biomass of the aquatic plant community in the TZ increased from $9.21 \pm 2.16$ to $16.51 \pm$ $4.44 \mathrm{~kg} / \mathrm{m}^{2}$, an increase of $79 \%$, of which the biomass of Trapa accounted for about $42 \%$ (Figure 4A). During the observation period after February 2016, the maximum and minimum aquatic plant community biomass in the NTZ were $21.73 \pm 1.43$ and $4.90 \pm 0.86 \mathrm{~kg} / \mathrm{m}^{2}$, respectively, while the maximum and minimum aquatic plant community biomass in the $\mathrm{TZ}$ were $13.27 \pm 2.16$ and $1.69 \pm 0.70 \mathrm{~kg} / \mathrm{m}^{2}$; these two indicators of the TZ were far lower than those of the NTZ $(p<0.05)$ (Figure 4A). The other three indicators of aquatic plant communities had similar changing trends, and the values of the three in the TZ were significantly higher than those in the NTZ $(p<0.05)$ throughout the experiment period (Figures 4B-D).

The structure of the aquatic plant community in the NTZ changed significantly after harvesting of Trapa. In the following two growing seasons (June-August), $P$. maackianus and $C$. demersum became the first dominant species in turn, and $C$. demersum was the first dominant species in each winter (Figure 5A). In the $\mathrm{TZ}$, the first dominant species in the annual growing season was Trapa, $P$. maackianus accounted for the largest proportion of biomass in most other months, and the biomass proportion of $C$. demersum was significantly lower than that of the NTZ after two years $(p<0.05)$ (Figure 5B).

\section{DISCUSSION}

\section{Local Water Quality Improved by Trapa Removal}

Before harvest, the concentrations of main nitrogen and phosphorus indexes (TN, DN, TP, and DP) in both the zones were at high levels. However, in the following growing seasons after harvesting, the concentrations of these parameters in the NTZ decreased significantly comparable to those in the TZ. Trapa 

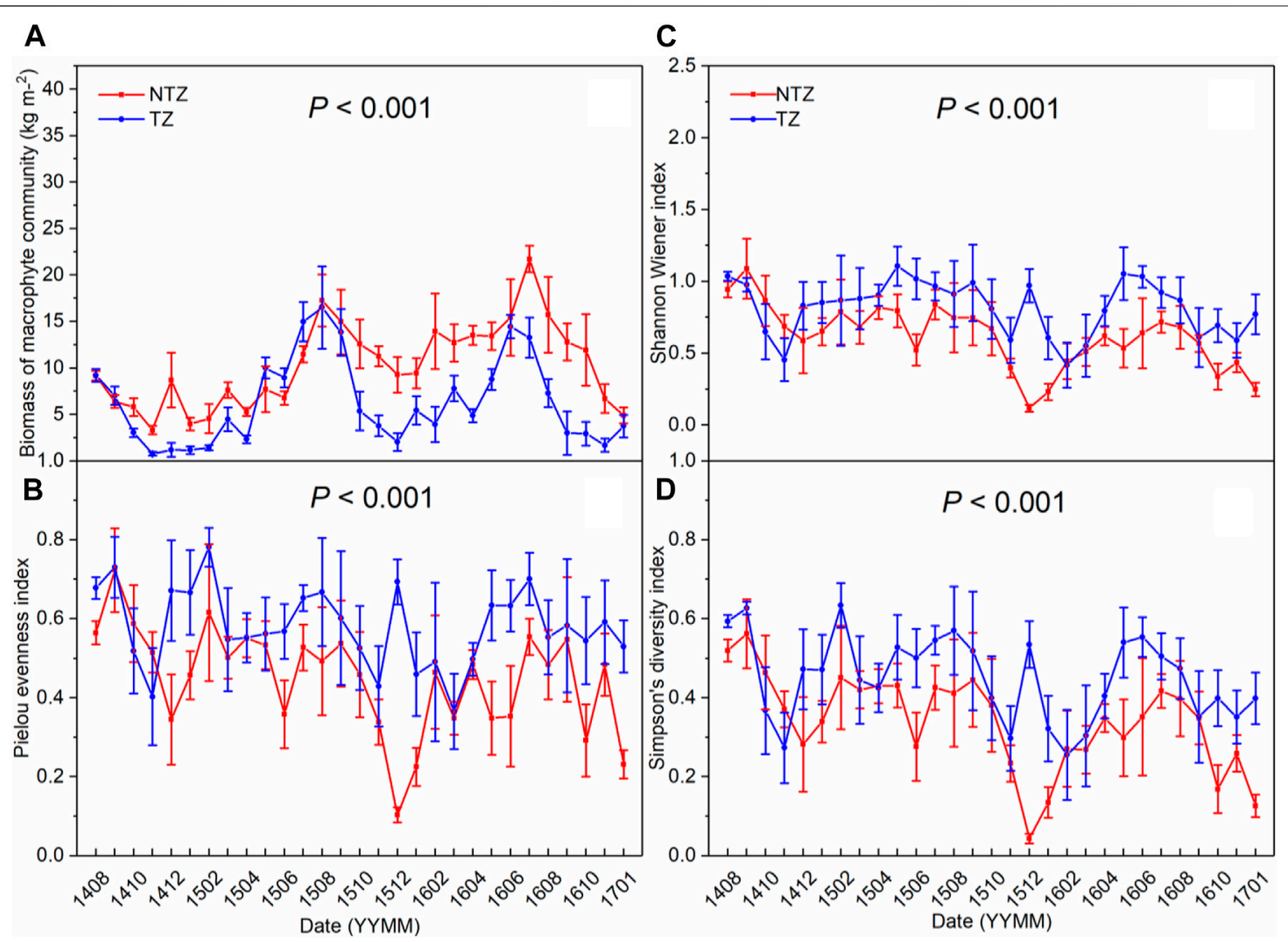

FIGURE 4 | Changing of biomass and biodiversity of macrophyte community in two zones (NTZ, non-Trapa zone; TZ, Trapa zone; number of replicates: 12). (A) biomass of macrophyte community; (B) Shannon-Weiner index; (C) Pielou's evenness index; (D) Simpson's diversity index.

had strong photosynthesis during the growing season, but it was mainly concentrated above the water surface. The oxygen produced by its photosynthesis is rarely diffused into the water, which formed a state of low oxygen concentration in the water body during the growing season (Caraco and Cole, 2002; Hummel and Findlay, 2006; Kara et al., 2010; Kornijow et al., 2010). In addition, due to Trapa's shading effect, the intensity of the light radiating through the water surface was very weak (Nurminen, 2008; Netten, 2011). After harvesting, the underwater light intensity and dissolved oxygen concentration might be significantly improved, so the biogeochemical process of the water body would be significantly promoted, and might greatly reduce the contents of nutrients and organic matter in the water column (Galanti et al., 1990). Due to the higher oxygen concentration in the NTZ after harvesting of Trapa, the oxidation and precipitation process of $\mathrm{PO}_{4}{ }^{3-}$ might be enhanced (Jensen et al., 1992; Caraco and Cole, 2002), which might be the reason why the three phosphorus indicators in the NTZ maintained relatively lower levels. In addition, after the harvesting, the biomass of aquatic plant community increased significantly in the NTZ, possibly absorbing more nitrogen and phosphorus nutrients, and further reducing the concentrations of nitrogen and phosphorus indicators.

There was no significant difference in the Chl-a concentration in the two zones in most months of the entire monitoring cycle. The dominant aquatic plants in these two zones might have different controlling roles on phytoplankton. After harvesting of Trapa, the biomass of aquatic plant community increased significantly, which might improve the allelopathy (van Donk and van de Bund, 2002) and the competitiveness of submerged macrophytes to phytoplankton in light intensity and nutrients (Asaeda et al., 2001), and might also indirectly restrain phytoplankton by providing shelter for zooplankton to enhance its predation to phytoplankton (Schriver et al., 1995). However, in the TZ, Trapa mainly inhibits the growth of phytoplankton through the shading effect shown by the water body and the low-oxygen environment under water (Ji et al., 2016). In addition, attached or free-living bacteria associated with some Trapa species have potentials to kill or inhibit the growth of cyanobacteria (Miyashita et al., 2019), which might cause the low Chl-a concentration.

Trapa is rich in starch and protein and has a high edible value (Xue et al., 2017); therefore, there are large amounts of its artificial cultivation in Erhai Lake. However, during its growing season, the rapid increase of nitrogen and phosphorus concentration and the decrease of dissolved oxygen in water have significant negative effects on the biological groups in local ecosystem. Previous studies have shown that the low-oxygen environment in areas covered by Trapa has a significant negative effect on some sensitive species (Hummel and Findlay, 2006), such as certain fish and invertebrates (Caraco and Cole, 2002). In addition, the 

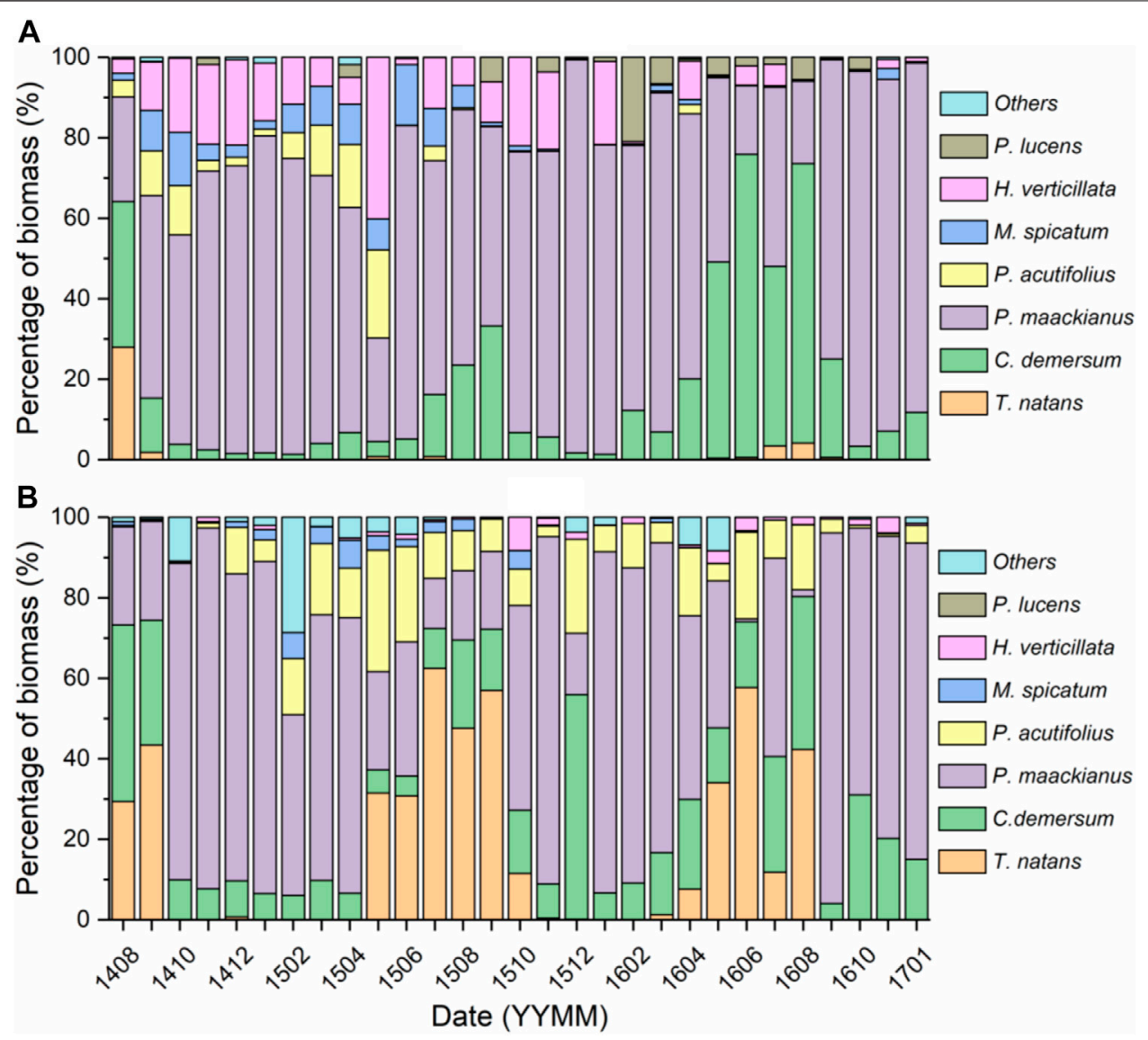

FIGURE 5 | Proportion of biomass of each species in aquatic plant community of two zones ((A) for non-Trapa zone, (B) for Trapa zone, number of replicates: 12).

growth of Trapa is more dependent on sediments than water (Xie et al., 2007), and absorbs a large amount of nitrogen and phosphorus nutrients from sediments (Li et al., 2010; Watanabe et al., 2010), and these nutrients are released into the water body after Trapa dies, causing a serious endogenous load. Therefore, from the perspective of improving local water quality, we believe that harvesting management of Trapa is necessary.

\section{Biodiversity in the Recovered Community}

Before harvesting, the structure and biomass of aquatic plant communities in the two zones were similar. After the removal of Trapa, biomass of aquatic plant community was significantly promoted, but its species diversity indicators declined to a certain extent. By the end of the experiment, $P$. maackianus and $C$. demersum in the aquatic plant community in the NTZ had absolute advantages, and the proportion of $C$. demersum had a tendency to further expand in the growing season. Harvesting Trapa can improve the habitats of the aquatic plant community (Carpenter and Gasith, 1978; Madsen et al., 1988) and provide growth opportunities for the propagule and/or dormant buds (Best, 1994; Xu et al., 2014). As canopy submerged macrophytes, P. maackianus and $C$. demersum might have obtained more growth space through different adaptation methods. P. maackianus is a common perennial canopy submerged plant in eutrophic water (Wang et al., 2003) and has a wide range of light adaptation (Song et al., 2014), and $C$. demersum is a non-root submerged plant adapting to a relatively wide range of nutrient concentration, and multiplies rapidly in summer and inhibits the growth of other species ( $\mathrm{He}$ et al., 2015). Due to the advantageous growth capacity and adaptability, they often form monodominant or polydominant communities in most bays of Erhai Lake (Ni, 2001; Ye et al., 2018). Their overgrowth might crowd out the living space of other species, and even result in the extinction of some sensitive species, for example, $H$. verticillata, thus leading to a significant decline in the number of species and biodiversity in the community.

They play a decisive role in the structure and function of aquatic plant communities in the shallow waters of Erhai Lake, and often cause a simple and unstable community structure in eutrophic waters. In addition, the biomass of $C$. demersum fluctuates greatly during the year ( $\mathrm{He}$ et al., 2015), and it declines in autumn (Dong et al., 2019) and then causes dramatic fluctuations in the community structure and composition, weakening the ecological function of the community (Sayer et al., 2010; Moore et al., 2020). Relevant studies have shown that it is reasonable to maintain a low coverage of $C$. demersum in eutrophic water bodies (Dai et al., 2012). Therefore, it is necessary to pay attention to the biomass change of $C$. demersum in the later stage and take timely management measures. 


\section{CONCLUSION}

Manual removal of Trapa can significantly improve the local water quality of the coastal water ecosystem in the northern bay of Erhai Lake, especially in the season of vigorous growth of aquatic plants. The removal of Trapa significantly increased the biomass of the aquatic plant community in summer and autumn, but it also had a negative impact on the internal composition of the submerged plant community, such as the decline in species diversity. In addition, $C$. demersum and $P$. maackianus became absolute dominant species. They played a leading role in the community structure in the later stage and may cause some negative effects in the long run, which require further attention and research.

\section{DATA AVAILABILITY STATEMENT}

The original contributions presented in the study are included in the article/Supplementary Material, and further inquiries can be directed to the corresponding author.

\section{REFERENCES}

Akabori, Y., Takagi, S., Nishihiro, J., and Kagami, M. (2015). Effects of FloatingLeaved Plant, Trapa Natans, on the Water Qualities in lake Inba. Jpn. J. Limnology (Rikusuigaku Zasshi) 77, 155-166. doi:10.3739/rikusui.77.155

Asaeda, T., Trung, V. K., Manatunge, J., and Van Bon, T. (2001). Modelling Macrophyte-Nutrient-Phytoplankton Interactions in Shallow Eutrophic Lakes and the Evaluation of Environmental Impacts. Ecol. Eng. 16, 341-357. doi:10.1016/S0925-8574(00)00120-8

Barko, J. W., and Smart, R. M. (1981). Comparative Influences of Light and Temperature on the Growth and Metabolism of Selected Submersed Freshwater Macrophytes. Ecol. Monogr. 51, 219-236. doi:10.2307/2937264

Best, E. P. H. (1994). The Impact of Mechanical Harvesting Regimes on the Aquatic and Shore Vegetation in Water Courses of Agricultural Areas of the Netherlands. Vegetatio 112, 57-71. doi:10.1007/BF00045100

Bolpagni, R., Pierobon, E., Longhi, D., Nizzoli, D., Bartoli, M., Tomaselli, M., et al. (2007). Diurnal Exchanges of $\mathrm{CO}_{2}$ and $\mathrm{CH}_{4}$ across the Water-Atmosphere Interface in a Water Chestnut Meadow (Trapa Natans L.). Aquat. Bot. 87, 43-48. doi:10.1016/j.aquabot.2007.02.002

Caraco, N. F., and Cole, J. J. (2002). Contrasting Impacts of a Native and Alien Macrophyte on Dissolved Oxygen in a Large River. Ecol. Appl. 12, 1496-1509. doi:10.1890/1051-0761(2002)012[1496:CIOANA]2.0.CO;2

Carpenter, S., and Gasith, A. (1978). Mechanical Cutting of Submersed Macrophytes: Immediate Effects on Littoral Water Chemistry and Metabolism. Water Res. 12, 55-57. doi:10.1016/0043-1354(78)90196-3

Chen, S., and Wang, D. (2019). Responses of Decomposition Rate and Nutrient Release of Floating-Leaved and Submerged Aquatic Macrophytes to Vertical Locations in an Urban lake (Nanhu Lake, China). Chem. Ecol. 35, 431-444. doi:10.1080/02757540.2019.1584615

Choi, E., Yoo, S., and Kim, H. (2016). Monitoring of Water Quality in Agricultural Reservoirs According to Trapa Japonica Death Effect. Korean J. Environ. Agric. 35, 148-151. doi:10.5338/KJEA.2016.35.2.17

Dai, Y., Jia, C., Liang, W., Hu, S., and Wu, Z. (2012). Effects of the Submerged Macrophyte Ceratophyllum Demersum L. On Restoration of a Eutrophic Waterbody and its Optimal Coverage. Ecol. Eng. 40, 113-116. doi:10.1016/ j.ecoleng.2014.06.00910.1016/j.ecoleng.2011.12.023

Dong, J., Chang, M., Li, C., Dai, D., and Gao, Y. (2019). Allelopathic Effects and Potential Active Substances of Ceratophyllum Demersum L. On Chlorella Vulgaris Beij. Aquat. Ecol. 53, 651-663. doi:10.1007/s10452-019-09715-2

\section{AUTHOR CONTRIBUTIONS}

$\mathrm{CY}, \mathrm{XB}, \mathrm{TZ}$, and $\mathrm{ZW}$ conducted long term field monitoring, data collection and analysis. XZ, TC, and LN conceive the research plan and provide funds. $\mathrm{CY}$ and $\mathrm{XZ}$ wrote and revised the manuscript.

\section{FUNDING}

This work was sponsored by the National Natural Science Foundation of China $(31870446,31930074)$ and the Science and Technology Service Network Initiative, Chinese Academy of Sciences (KFJ-STS-QYZD-156).

\section{ACKNOWLEDGMENTS}

We thank engineer Dehuo Long and the three villagers-Sheng Wang, Buliang Zhao, and Xiaoming Yang in Baima village, Shangguan Town, Dali City, for their contribution to the layout of the experimental area and their help in the sampling of this study.

Eaton, A. D., Clesceri, L. S., Greenberg, A. E., and Branson, M. H. (1995). Standard Methodsfor the Examination of Water and Wastewater. 19th ed. Washington, DC: American Public HealthAssociation. doi:10.3386/w5131

Fu, H., Yuan, G. X., Cao, T., Zhong, J. Y., Zhang, X. L., Guo, L. G., et al. (2013). Succession of Submerged Macrophyte Communities in Relation to Environmental Change in Lake Erhai over the Past 50 Years. J. Lake Sci. 25, 854-861. (in Chinese with an English abstract). doi:10.18307/2013.0609

Galanti, G., Guilizzoni, P., and Libera, V. (1990). Biomanipulation of Lago di Candia (Northern Italy): a three-year experience of aquatic macrophyte management. Hydrobiologia 200-201, 409-417. doi:10.1007/bf02530358

Goodwin, K., Caraco, N., and Cole, J. (2008). Temporal Dynamics of Dissolved Oxygen in a Floatingleaved Macrophyte Bed. Freshw. Biol 53, 1632-1641. doi:10.1111/j.1365-2427.2008.01983.x

He, L., Zhu, T., Cao, T., Li, W., Zhang, M., Zhang, X., et al. (2015). Characteristics of Early Eutrophication Encoded in Submerged Vegetation beyond Water Quality: a Case Study in Lake Erhai, China. Environ. Earth Sci. 74, 3701-3708. doi:10.1007/s12665-015-4202-4

Hummel, M., and Findlay, S. (2006). Effects of Water Chestnut (Trapa Natans) Beds on Water Chemistry in the Tidal Freshwater Hudson River. Hydrobiologia 559, 169-181. doi:10.1007/s10750-005-9201-0

Jensen, H. S., Kristensen, P., Jeppesen, E., and Skytthe, A. (1992). Iron:phosphorus Ratio in Surface Sediment as an Indicator of Phosphate Release from Aerobic Sediments in Shallow Lakes. Hydrobiologia 235-236, 731-743. doi:10.1007/ BF00026261

Ji, G., Xu, Z.-X., and Wang, L.-Q. (2016). Effects of Floating-Leaved Macrophytes on Water Quality and Phytoplankton: Anin Situexperiment in a Chinese Shallow lake. Desalination Water Treat. 57, 1-12. doi:10.1080/ 19443994.2016.1180641

Kagami, M., Nishihiro, J., and Yoshida, T. (2019). Ecological and Limnological Bases for Management of Overgrown Macrophytes: Introduction to a Special Feature. Limnology 20, 1-2. doi:10.1007/s10201-018-0565-z

Kara, G., Nina, C., and Jonathan, C. (2010). Temporal Dynamics of Dissolved Oxygen in a Floating-Leaved Macrophyte Bed. Freshw. Biol. 53, 1632-1641. doi:10.1111/j.1365-2427.2008.01983.x

Kato, Y., Nishihiro, J., and Yoshida, T. (2016). Floating-leaved Macrophyte (Trapa Japonica) Drastically Changes Seasonal Dynamics of a Temperate lake Ecosystem. Ecol. Res. 31, 695-707. doi:10.1007/s11284-016-1378-3

Klančnik, K., Iskra, I., Gradinjan, D., and Gaberscik, A. (2017). The Quality and Quantity of Light in the Water Column Are Altered by the Optical Properties of Natant Plant Species. Hydrobiologia 812, 203-212. doi:10.1007/s10750-017-3148-9 
Kočić, A., Topić, J., Horvatić, J., and Jelaska, S. D. (2009). Changes in Macrophyte Composition in Channels of the Bosut River basin (Eastern Croatia) between 1980-2006. In: 12th European Weed Research Society Symposium.

Kornijów, R., Strayer, D. L., and Caraco, N. F. (2010). Macroinvertebrate Communities of Hypoxic Habitats Created by an Invasive Plant (Trapa Natans) in the Freshwater Tidal Hudson River. fal 176, 199-207. doi:10.1127/1863-9135/2010/0176-0199

Lawniczak, A., and Achtenberg, K. (2018). On the Use of Macrophytes to Maintain Functionality of Overgrown lowland Lakes. Ecol. Eng. 113, 52-60. doi:10.1016/ j.ecoleng.2018.02.003

Li, K.-Y., Liu, Z.-W., and Guan, B.-H. (2010). Effects of Nutrient Levels in Surface Water and Sediment on the Growth of the Floating-Leaved Macrophyte Trapa Maximowiczii: Implication for Management of Macrophytes in East Bay of Lake Taihu, China. Limnology 11, 95-101. doi:10.1007/s10201-009-0293-5

Madsen, J. D., Adams, M. S., and Ruffier, P. (1988). Harvest as a Control for Sago Pondweed (Potamogeton Pectinatus L.) in Badfish - Creek, Wisconsin Frequency, Efficiency and its Impact on the Stream Community Oxygen Metabolism. J. Aquat. Plant Manage. 26, 20-25.

Markovic, G., Vicentijevic-markovic, G., and Tanaskovic, S. a. (2015). First Record of Water Chestnut (Trapa Natans L., Trapaceae, Myrtales) in Central Serbia. Jcea 16, 436-444. doi:10.5513/JCEA01/16.4.1650

Miyashita, Y., Hagiwara, T., and Imai, I. (2019). The Existence of Cyanobactericidal Bacteria and Growth-Inhibiting Bacteria on Water Plants in Lake Ohnuma, Japan. Limnology 20, 39-53. doi:10.1007/s10201-018-0542-6

Moore, T. P., Clearwater, S. J., Duggan, I. C., and Collier, K. J. (2020). Invasive Macrophytes Induce Context-specific Effects on Oxygen, $\mathrm{pH}$, and Temperature in a Hydropeaking Reservoir. River Res. Applic 36, 1717-1729. doi:10.1002/ rra. 3674

Netten, J. J. C. (2011). Competition between Free-Floating and Submerged Macrophytes in a Future of Climate Change.

$\mathrm{Ni}$, L. (2001). Growth ofPotamogeton Maackianusunder Low-Light Stress in Eutrophic Water. J. Freshw. Ecol. 16, 249-256. doi:10.1080/ 02705060.2001.9663809

Nurminen, L. (2008). Diurnal Variation in Light Intensity underneath Floating Macrophyte Leaves and Implications for the Behaviour of Plant-Attached Zooplankton. Biol. Rhythm Res. 39, 349-357. doi:10.1080/09291010701425033

Sayer, C. D., Davidson, T. A., and Jones, J. I. (2010). Seasonal Dynamics of Macrophytes and Phytoplankton in Shallow Lakes: a Eutrophication-Driven Pathway from Plants to Plankton? Freshw. Biol. 55, 500-513. doi:10.1111/ j.1365-2427.2009.02365.x

Scheffer, M., Szabó, S., Gragnani, A., van Nes, E. H., Rinaldi, S., Kautsky, N., et al. (2003). Floating Plant Dominance as a Stable State. Proc. Natl. Acad. Sci. 100, 4040-4045. doi:10.1073/pnas.0737918100
Schriver, P., Bogestrand, J., Jeppesen, E., and Sondergaard, M. (1995). Impact of Submerged Macrophytes on Fish-Zooplanl Phytoplankton Interactions: LargeScale Enclosure Experiments in a Shallow Eutrophic lake. Freshw. Biol. 33, 255-270. doi:10.1111/j.1365-2427.1995.tb01166.x

Song, X., Cao, T., Zhu, G. R., Li, W., Zhang, X. L., and Ni, L. Y. (2014). Adaptive Comparison of Potamogeton Maackianus and P. Malaianus to Various Water Depths in an Experimental Study. Resour. Environ. Yangtze Basin 23, 1081-1089. (in Chinese with an English abstract).

van Donk, E., and van de Bund, W. J. (2002). Impact of Submerged Macrophytes Including Charophytes on Phyto- and Zooplankton Communities: Allelopathy versus Other Mechanisms. Aquat. Bot. 72, 261-274. doi:10.1016/S0304-3770(01)00205-4

Wang, X. M., Sun, S. G., and Guo, Y. H. (2003). A Primary Study of Germination Characteristic of Potamogeton Maackianus. Acta Hydrobiol. Sinica 27, 95-97. (in Chinese with an English abstract).

Watanabe, M., Koyama, T., and Sasaki, H. (2010). The Proposal for Nutrient Concentration Control Employing Nutrient Uptake and Release by Trapa Japonica Inhabiting Lake Izunuma. Mizu Kankyo Gakkaishi 33, 57-61. doi:10.2965/jswe.33.57

Xie, Y., Lei, Z., Li, C. H., and Liu, Z. W. (2007). Effects of Sediment and Overlying Water from Meiliang Bay of Taihu Lake on the Growth of Trapa Quadrispinosa Roxb. Ecol. Environ. 16, 753-757. doi:10.1016/S1872-2032(08)60016-5

Xu, W., Hu, W., Deng, J., Zhu, J., and Li, Q. (2014). Effects of Harvest Management of Trapa Bispinosa on an Aquatic Macrophyte Community and Water Quality in a Eutrophic lake. Ecol. Eng. 64, 120-129. doi:10.1016/j.ecoleng.2013.12.028

Xue, Z.-Q., Xue, J.-H., Victorovna, K. M., and Ma, K.-P. (2017). The Complete Chloroplast DNA Sequence of Trapa Maximowiczii Korsh. (Trapaceae), and Comparative Analysis with Other Myrtales Species. Aquat. Bot. 143, 54-62. doi:10.1016/j.aquabot.2017.09.003

Ye, B., Chu, Z., Wu, A., Hou, Z., and Wang, S. (2018). Optimum Water Depth Ranges of Dominant Submersed Macrophytes in a Natural Freshwater lake. PLoS One 13, e0193176. doi:10.1371/journal.pone.0193176

Conflict of Interest: The authors declare that the research was conducted in the absence of any commercial or financial relationships that could be construed as a potential conflict of interest.

Copyright $\odot 2021$ Yuan, Bai, Zhu, Wen, Cao, Zhang and Ni. This is an open-access article distributed under the terms of the Creative Commons Attribution License (CC BY). The use, distribution or reproduction in other forums is permitted, provided the original author(s) and the copyright owner(s) are credited and that the original publication in this journal is cited, in accordance with accepted academic practice. No use, distribution or reproduction is permitted which does not comply with these terms. 